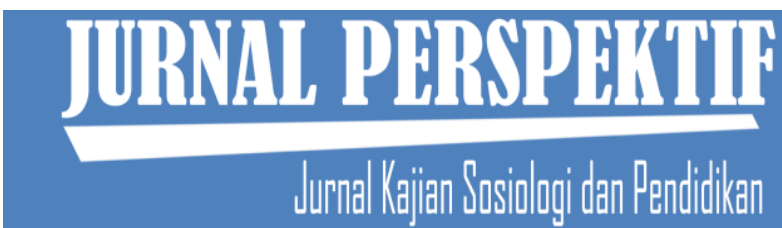

Jurnal Perspektif: Jurnal Kajian Sosiologi dan Pendidikan Vol. 2 No. 3 Tahun 2019

http://perspektif.ppj.unp.ac.id

Email: perspektif@ppj.unp.ac.id

ISSN: 2622-1748 (Online), 2684-902X (Print)

DOI: http://dx.doi.org/10.24036/perspektif.v2i3.85

\title{
Faktor-Faktor Penyebab Kepatuhan Siswa Kelas XI dalam Mematuhi Peraturan di SMA Negeri 2 Bukittinggi
}

\author{
Santalia Hasugian', Mira Hasti Hasmira ${ }^{2}$ \\ 1,2Universitas Negeri Padang \\ email: santaliahasugian02@gmail.com, mirahasti@ fis.unp.ac.id
}

\begin{abstract}
Abstrak
Pelitian ini dilatar belakangi kepatuhan kelas XI lebih meningkat dibanding kelas X dan XII. padahal kelas XI itu mengalami tahap menentang (trotzalter). Tujuan penelitian untuk mengetahui, menjelaskan dan mendeskripsikan Faktor-faktor penyebab kepatuhan pada siswa kelas XI dalam mematuhi peraturan di SMA Negeri 2 Bukittinggi. Teori penelitian ini Teori kontrol sosial yang dikemukakan oleh Hirschi. Metode penelitian yang digunakan deskriptif kualitatif. Metode pengumpulan data berupa observasi, Wawancara, dan studi dokumentasi. Teknik analisis data model analisis interaktif oleh Miles dan Huberman. Hasil penelitian menunjukkan faktor-faktor penyebab kepatuhan pada siswa kelas XI terdiri dari dua faktor. Faktor Eksternal yaitu, kontrol sosial cara lisan, hukuman berupa menghafal al-qur'an dan GBLS, input siswa kelas XI dan ceramah dari guru mata pelajaran yang sedang mengajar. Faktor internal yaitu, takut dimarahi orang tua, kesadaran diri sendiri, ejekan teman sebaya, merasa tanggung jawab sebagai siswa, kontrol sosial guru di kelas, takut nilai kedisiplinan (C), motivasi diri sendiri.
\end{abstract}

Kata Kunci: Faktor-faktor, Kepatuhan, Peraturan, Siswa

\section{Abstrack}

This background is based on the obedience of class XI which is more elevated compared to classes X and XII. Eventhough class XI is experiencing a stage of opposition (trotzalter). The purpose of the study was to find out, explain and describe the Factors that cause compliance in Class XI Students in complying with regulations in Bukittinggi 2 Public High School. This research theory Theory of social control proposed by Hirschi. The research method used is descriptive qualitative. Methods of collecting data in the form of observation, interviews, and documentation studies. Data analysis techniques are interactive analysis models by Miles and Huberman. The results of the study showed that the factors causing compliance in Class XI Students consisted of two factors. External factors, namely, social control of verbal means, punishment in the form of memorize the Qur'an and GBLS, input of class XI students and lectures from subject teachers who are teaching. Internal factors, namely, fear of being scolded by parents, self-awareness, peer teasing, feeling responsibility as a student, social control of teachers in the classroom, fear of disciplinary values $(C)$, selfmotivation.

Keywords: Factors, Compliance, Regulations, Students

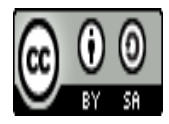

Received: July 26, $2019 \quad$ Revised: August 1, $2019 \quad$ Available Online: August 2, 2019 


\section{Pendahuluan}

Sekolah merupakan sebuah lembaga sosial atau institusi formal dirancang untuk proses pendidikan yang tidak terlepas dari aturan, aturan dibuat untuk ketertiban seluruh warga sekolah terutama kedisiplinan. Kedisiplinan siswa merupakan hal yang sangat penting bagi kemajuan sekolah. Dengan adanya kedisplinan dapat membuat suasana belajar efektif dan efesien. Setiap satuan pendidikan berupaya untuk merencanakan, menciptakan dan berupaya memberikan pengajaran pendidikan agar para peserta didik menjadi insan yang diharapkan yang memiliki pribadi luhur. Tidak disilplinnya siswa merupakan perbuatan yang tidak sesuai dengan nilai maupun aturan yang ditetapkan oleh sekolah. Perbuatan tersebut akan berdampak buruk pada semua pihak baik itu diri siswa itu sendiri, orangtua, guru dan semua orang yang ada dilingkunagan sekolah.

Keberhasilan sekolah dalam melaksanakan program pendidikan bagi peserta didik tidak hanya ditentukan oleh apa yang dilakukan dan disediakan sekolah untuk peserta didiknya, seperti kurikulum yang sempurna, proses belajar mengajar yang dilakukan guru, serta sarana dan prasarana pendidikan yang lengkap saja tetapi juga ditentukan oleh lingkungan keluarga peserta didik dan masyarakat sekitar.(Yahya, 2018)

Pelanggaran terhadap tata tertib banyak dijumpai di sekolah-sekolah yang umumnya dilakukan oleh para siswa, terutama masalah keterlambatan yang merupakan salah satu pelanggaran paling sering kali dilakukan siswa. Perilaku terlambat datang ke sekolah merupakan perilaku maladaptif yang sering kali dijumpai di lembaga pendidikan. Tidak terkecuali juga di SMA N 2 Bukittinggi atau dikenal dengan Kweek School (Sekolah Raja) yang merupakan salah satu SMA terakreditasi "A" yang ada di Kota Bukittinggi.

Adapun pelanggaran yang telah dilakukan siswa SMA Negeri 2 Bukittinggi adalah banyak siswa yang hadir tidak tepat waktu atau banyak yang terlambat setiap pagi, tidak lengkap memakai atribut yang diberikan sekolah, alpha, kaos kaki yang tidak sesuai aturan sekolah yaitu kaos kaki putih, bolos, merokok, baju kurung pendek atau ketat, celana sempit, main hp saat proses belajar mengajar, membeli makanan saat proses belajar mengajar berlangsung, tidak sholat dzuhur berjama'ah dilapangan SMA N 2 Bukittinggi.

Ada beberapa bentuk kontrol sosial yang diberikan pihak SMA N 2 Bukittinggi terhadap siswa yang terlambat yaitu dengan memberikan sanksi. Sanksi itu dilaksanakan dengan cara, awalnya siswa yang terlambat mengisi buku pelanggaran yang dibuat sekolah. Setelah itu, mereka menyiram bunga yang ada dilingkungan sekolah dan bunga-bunga yang ada di lantai satu sampai lantai tiga. Kemudian diwajibkan untuk menghafal al-qur'an dan menyetor hafalan sebanyak ayat dan surah yang telah ditentukan selanjutnya diserahkan kepada konselor sekolah.

SMA N 2 Bukittinggi sudah membuat kebijakan untuk membiasakan hidup disiplin. Hari Senin dan Jum'at bel berbunyi pukul 07.10 seluruh masyarakat sekolah wajib mengikuti kegiatan upacara bendera pada hari Senin dan kultum hari Jum'at. Hari Selasa, Rabu, Kamis, dan Sabtu Pukul 07.15 bel sekolah sudah berbunyi pertanda semua siswa harus masuk kelas untuk mengikuti proses belajar mengajar dan gerbang sekolah ditutup oleh security sekolah. Bagi yang terlambat diberikan hukuman sebagai bentuk kontrol sosial dari sekolah. 
Santalia Hasugian, Mira Hasti Hasmira

Tabel 1. Keterlambatan Siswa Kelas X, XI, XII SMA N 2 Bukittinggi Bulan Agustus, September, Oktober Tahun 2018/2019.

\begin{tabular}{cccc}
\hline \multirow{2}{*}{ Kelas } & \multicolumn{3}{c}{ Bulan } \\
\cline { 2 - 4 } & Agustus & September & Oktober \\
\hline X & 50 & 23 & 31 \\
\hline XI & 85 & 36 & 31 \\
\hline XII & 99 & 76 & 85
\end{tabular}

(Sumber: Buku Pelanggaran SMA Negeri 2 Bukittinggi Tahun Ajaran 2018/2019).

Dari tabel di atas dapat dilihat bahwa jumlah keterlambatan siswa tiga bulan terakhir pada bulan Agustus, September, Oktober. Pada kelas X awalnya meningkat, menurun dan kembali meningkat. Pada kelas XI keterlambatan semakin menurun atau kedisiplinan siswa semakin meningkat. Pada kelas XII sama hal nya dengan kelas X awalnya keterlambatan siswa meningkat, menurun, dan kembali meningkat. Sekolah menengah atas rata-rata usia 1617 tahun bisa dikatakan usia remaja. Masa remaja yang sering kali dikenal dengan mencari jati diri. Oleh Erickson disebut dengan identitas ego (ego identity) dan fase remaja berusaha melepaskan diri dari lingkungan orang tua untuk menemukan jati diriny.

Pada periode ini juga perkembangan remaja mengalami tahapan yang disebut dengan masa menentang (trotzalter). Tahapan ini ditandai dengan adanya perubahan yang sangat mencolok pada diri remaja yaitu pada aspek fisik maupun psikis. Remaja juga memiliki kecendrungan untuk melakukan pelanggaran terhadap otoritas. (Asrori, 2004)

Usia remaja usia 16-17 tahun itu adalah kelas XI. Kelas XI biasanya yang sangat banyak ditemui berkasus. Kelas $\mathrm{X}$ karena masih siswa baru mereka berusaha untuk mengenali lingkungan dan taat pada peraturan sekolah. Kelas XII karena sudah tidak lama lagi meninggalkan sekolah maka guru lebih banyak memotivasi agar bisa memberi kesan yang baik ketika sudah jadi alumni dan XII juga sudah banyak sibuk dengan ujian-ujian persiapan UN sampai UN. Berdasarkan data kelas XI lebih patuh terhadap peraturan. Oleh karena itu, sesuai dengan uraian di atas maka peneliti tertarik untuk meneliti masalah tentang Faktor-faktor Penyebab Kepatuhan Pada Siswa Kelas XI Dalam Mematuhi Peraturan di SMA Negeri 2 Bukittinggi.

Terlambat datang ke sekolah merupakan suatu hal yang cukup fatal akibatnya contoh siswa kelas XI yang berisinial "S" bel sudah berbunyi pertanda masuk kelas jam pertama dan kegiatan belajar mengajar sudah dimulai siswa tersebut baru sampai di sekolah dan tidak bisa langsung masuk kelas karena harus diproses terlebih dahulu oleh guru piket hari itu sehingga siswa tersebut tidak mengikuti jam pertama dan masuk pada jam kedua. Mengingat betapa pentingnya kedisiplinan terutama katepatan waktu sangat perlu untuk dibina dengan baik, dari uraian diatas peneliti tertarik ingin melakukan penelitian dengan judul: "Faktor-faktor Penyebab Kepatuhan Pada Siswa Kelas XI Dalam Mematuhi Peraturan di SMA Negeri 2 Bukittinggi”.

Kepatuhan adalah menerima perintah-perintah dari orang lain. Kepatuhan dapat terjadi dalam bentuk apapun, selama individu tersebut menunjukkan perilaku taat terhadap sesuatu atau seseorang. Misalnya kepatuhan terhadap norma sosial. (Blass, 1999). Kepatuhan terhadap norma sosial dapat dirumuskan sebagai sikap yang tunduk pada aturan-aturan dan nilai dalam kelompok sosial masyarakat dalam bentuk lisan maupun tulisan yang disepakati bersama dengan tulus agar setiap individu menjalankan perannya secara terstruktur dan seluruh kegiatannya berjalan dengan baik serta meninggalkan apa yang menjadi larangannya agar terhindar dari sanksi hukuman.

Jurnal Perspektif: Jurnal Kajian Sosiologi dan Pendidikan Vol. 2, No. 3, Th. 2019 ISSN. 2622-1748 
Sanksi merupaka bentuk penderitaan, kerugian beban berat yang sengaja diciptakan oleh lembaga sosial untuk memaksa anggota masyarakat agar taat pada norma yang ada. Salah satu sanksi yang digunakan di dalam usaha menciptakan tertib sosial adalah sanksi psikologis yang mana sanksi psikologis ini merupakan beban penderitaan yang dikenakan pada pihak yang terbebani sanksi dengan beban kejiwaan, seperti dipermalukan di depan umum, diumumkan kejahatan mereka di berbagai media massa sehingga aibnya diketahui oleh khalayak, dicopot pangkatnya di suatu upacara dan sebagainya. Sanksi psikologis merupakan langkah pertama dalam bentuk peringatan atau ancaman. Sanksi Psikologis ini berlaku dalam bentuk peringatan agar anggota masyarakat kembali ke "jalan yang benar" (Kholid, 2011)

Disiplin adalah suatu sikap menghormati, menghargai, patuh, dan taat terhadap peraturan-peraturan yang berlaku, baik yang tertulis maupun tidak tertulis serta sanggup menjalankannya dan tidak mengelak untuk menerima sanksi-sanksinya apabila ia melanggar tugas dan wewenang yang diberikan kepadanya. (Siswanto, 2001)

"1 Mei 1974, No.14/ U/ 1974 dalam Suryo Subroto (2004:81) Tata tertib sekolah adalah ketentuan-ketentuan yang mengatur kehidupan sekolah sehari-hari dan mengandung sanksi terhadap pelanggarnya. Pendapat tersebut dapat ditarik kesimpulan bahwa tata tertib sekolah adalah aturan yang mengatur kehidupan sekolah dan harus dipatuhi oleh setiap warga sekolah baik itu siswa, guru, tata usaha maupun kepala sekolah.” (Julia, 2013)

Kajian-kajian mengenai Kepatuhan siswa dalam menaati peraturan sekolah telah dilakukan oleh Tsania Rizqi Laila (2018) dalam Skripsi yang berjudul "Hubungan Kekuatan Kerakter dan Kepatuhan Santri pada Peraturan Pondok Pesantren".(Tsania Rizqi Laila, 2018) Anita Dwi Rahmawati (2015) dalam Skripsi yang berjudul "Kepatuhan Santri Terhadap Peraturan di Pondok Pesantren”. (Rahmawati, 2015). Apriliani Fitri (2015) "Upaya Guru Dalam Meningkatkan Kedisiplinan Siswa di SMA PP DR M. Natsir Batu Bagiriak Kecamatan Lembah Gumanti Kabupaten Solok.(Apriliani Fitri, 2015)

Kajian-kajian yang telah diuraikan di atas memiliki kesamaan dengan yang peneliti teliti yaitu sama-sama mengkaji tentang kepartuhan siswa dalam mematuhi peraturan sekolah. Namun, memiliki perbedaan yaitu tempat penelitiannya berbeda penelitian yang telah diuraikan di atas memfokuskan pada masalah yang diangkat oleh peneliti sebelumnya cakupannya lebih luas yaitu pelanggaran tata tertib secara umum. Sedangkan, penelitian yang akan dilakukan peneliti adalah untuk mengetahui faktor-faktor penyebab kepatuhan pada siswa kelas XI dalam Mematuhi Peraturan di SMA Negeri 2 Bukittinggi.

Tujuan penelitian ini adalah untuk mengetahui, menjelaskan dan mendeskripsikan Faktor-Faktor Penyebab Kepatuhan Pada Siswa Kelas XI dalam Mematuhi Peraturan di SMA Negeri 2 Bukittinggi.

Melihat siswa kelas XI adalah siswa yang berbeda siswa kelas lain. Biasanya siswa yang terkenal melanggar peraturan sekolah adalah siswa kelas XI. Namun, pada data yang ditemukan kelas XI keterlambatannya menurun. Maka pertanyaan yang peneliti ajukan adalah Apa saja Faktor-Faktor Penyebab Kepatuhan Pada Siswa Kelas XI Dalam Mematuhi Peraturan di SMA Negeri 2 Bukittinggi?

Hirschi mengajukan beberapa proposisi teoritisnya, yaitu: Bahwa berbagai bentuk pengingkaran terhadap aturan-aturan sosial adalah akibat dari kegagalan mensosialisasi individu masyarakat untuk bertindak konform terhadap aturan atau tata tertib yang ada. Penyimpangan dan bahkan kriminalitas atau perilaku kriminal merupakan bukti kegagalan kelompok-kelompok sosial konvensional untuk meningkatkan individu agar tetap konform, seperti: keluarga, sekolah, atau institusi pendidikan dan kelompok-kelompok dominan 
lainnya. Setiap individu harus belajar untuk konform dan tidak melakukan tindakan menyimpang atau kriminal. Kontrol internal lebih berpengaruh daripada kontrol eksternal.

Masih berdasarkan proposisi Hirschi, kurang lebih ada empat unsur utama di dalam kontrol sosial internal, yaitu attachemen (kasih sayang), commitment (tanggung jawab), involvement (keterlibatan atau partisipasi), dan belive (kepercayaan/keyakinan). Keempat unsur tersebut dianggap merupakan social bonds yang berfungsi untuk mengendalikan perilaku individu. (Suyanto Bagong dan J. Dwi Narwoko, 2011)

\section{Metode Penelitian}

Peneliti melakukan penelitian di SMAN 2 Bukittinggi Jalan Sudirman No.5 Desa Sapiran, Kecamatan Aur Birugo Tigo Baleh, Kota Bukitttinggi, Sumatera Barat. Jenis penelitian yang digunakan adalah metode penelitian deskriptif kualitatif. Informan ditentukan berdasarkan purposive sampling. Purposive sampling adalah peneliti menentukan pengambilan sampel dengan cara menetapkan ciri khusus yang sesuai dengan tujuan penelitian sehingga diharapkan dapat menjawab permasalahan penelitian. (Melleong J. Lexy, 2009)

Pada penelitian ini menurut peneliti informan sebanyak 29 orang sudah cukup karena peneliti telah menemukan kejenuhan data dari yang dikaji. 29 orang informan menjawab pertanyaan dengan jawaban yang sama. Oleh sebab itu, peneliti mencukupkan informan 29 orang. Peneliti menentukan yang menjadi informan dalam penelitian adalah Kepala Sekolah, Wakil kepala sekolah bidang kesiswaan, Guru piket, Guru Bimbingan dan Konseling, wali kelas XI, siswa kelas XI SMA N 2 Bukittinggi yang terlambat, dan siswa yang tidak terlambat.

Metode pengumpulan data yang dimaksud dalam penelitian ini adalah Observasi yang digunakan peneliti dalam penelitian ini adalah observasi partisipasi active (Active Participation). (Bungin Burhan M, 2007: 118). Peneliti datang ke tempat penelitian (SMA N 2 Bukittinggi) mengamati dan melakukan observasi juga ikut dalam kegiatan tersebut. Wawacara yang dilakukan dalam penelitian ini adalah wawancara mendalam (Indepth Interview). Pada penelitian ini dokumentasi yang dibutuhkan peneliti adalah buku pelanggaran siswa, buku tata tertib SMA N 2 Bukittinggi, gambar-gambar siswa/i terlambat sedang mengerjakan sanksi yang diberikan guru piket, gambar-gambar ketika peneliti dan informan sedang melakukan wawancara dan dokumentasi yang lain yang mendukung masalah yang dikaji. Analisis yang digunakan adalah analisis model Miles dan Huberman

\section{Hasil dan Pembahasan}

\section{Faktor-Faktor Penyebab Kepatuhan Siswa Kelas XI dalam Mematuhi Peraturan Di SMA Negeri 2 Bukittinggi}

\section{Penyebab Siswa Terlambat}

Keterlambatan yang terjadi pada siswa/i ada yang disengaja dan ada yang tidak disengaja. Keterlambatan disengaja maksudnya keterlambatan yang disebabkan kelalaian sendiri seperti main game online sampai larut malam, menonton drama korea sampai larut malam, tidak mempersiapkan perlengkapan sekolah pada malam harinya seperti buku seragam sekolah dan perlengkapan sekolah lainnya, mengerjakan PR pagi hari, bangun kesiangan sehingga terlambat ke sekolah. siswa yang rumahnya dekat dengan sekolah banyak yang terlambat karena mereka menunggu bel terlebih dahulu baru berangkat kadang bel sudah berbunyi ditunggu 5 menit dulu berlalu beru ke sekolah sehingga terlambat. 
Keterlambatan yang tidak disengaja ini khususnya siswa yang agak jauh dari sekolah kalau pagi-pagi harus menunggu lama berangkat karena angkotnya terbatas, angkot akan berangkat ketika angkot sudah penuh. Kalau sudah lewat angkot pertama lama lagi menunggu angkot sehingga bisa menyebabkan siswa terlambat. Ada yang membantu orangtuanya terlebih dahulu pagi-pagi baru berangkat sekolah, menunggu adiknya yang susah bangun pagi karena adiknya harus diantar sekolah terlebih dahulu.

Peneliti menganalisis dengan teori kontrol sosial keterlambatan yang disengaja merupakan keterlambatan karena kekalaian siswa itu sendiri dan tidak ada aturan yang tegas untuk mengontrol siswa tersebut sebagaimana ide utama dari teori ini bahwa penyimpangan marupakan hasil dari kekosongan kontrol sosial atau pengendalian sosial seperti yang telah di uraikan diatas orangtua tidak membuat aturan yang tegas terhadap siswa di rumah sehingga mereka para siswa bermain game online dan menonton drama korea sampai larut malam, PR dikerjakan pagi, tidak mempersiapkan perlengkapan sekolah pada malam, baik itu buku-buku dan seragam sekolah, dan untuk siswa yang dekat rumahnya dengan sekolah orang tua kurang tegas menyuruh siswa tersebut untuk lebih awal berangkat, ini merupakan proposisi dari teori Hirschi bahwa tidak adanya sanksi yang tegas dari orangtua di rumah menyebabkan pengingkaran terhadap aturan-aturan sosial di sekolah dan hal ini merupakan kegagalan mensossialisasi siswa tersebut untuk mematui tata tertib yang ada.

Kemudian menurut Hirschi Penyimpangan merupakan bukti dari kegagalan kelompokkelompok konvensional untuk meningkatkan individu mematuhi peraturan yang ada termasuk disini adalah keluarga karena kurang memberikan pengawasan terhadap siswa dan dari informan siswa yang terlambat mengatakan orang tua membangunkan pagi-pagi tapi hanya sekedarnya saja dan orang tua pergi duluan kerja sedangkan siswa belum berangkat ke sekolah sehingga siswa kesiangan bangun dan terlambat ke sekolah.

Pada proposisi teoritisnya Hirschi bahwa setiap individu harus belajar untuk konform atau mematuhi peraturan sekolah dan tidak melakukan tindakan penyimpangan. siswa yang terlambat harus belajar untuk tepat waktu datang ke sekolah dengan cara mengubah perilaku keterlambatan datang ke sekolah menjadi tepat waktu atau disiplin. Bagi siswa yang keterlambatannya tidak disengaja bangun lebih cepat dan naik angkot lebih cepat supaya tidak ketinggalan angkot dan mengusahakan naik angkot yang pertama supaya lebih cepat sampai di sekolah karena kalau menunggu angkot lagi akan lebih lama menunggu dan itu membuat siswa terlambat, ada juga siswa yang terlambat ini orang tuanya dipanggil ke sekolah dan mengetahui anaknya sering terlambat karena sering ketinggalan angkutan umum dari informasi yang peneliti peroleh bahwa orang tua membeli kendaraan seperti motor supaya anaknya tidak terlambat lagi. Bagi siswa yang keterlambatannya disengaja karena berbagi aktivitas yang dilakukan sehingga membuat lalai siswa yang seperti ini belajar untuk konform karena orangtua nya yang marah karena orang tua merasa kecewa dan siswa taku dimarahi lagi dan belajar untuk disiplin.

Menurut Hirschi juga kontrol internal lebih berpengaruh daripada kontrol sosial eksternal. Keluarga merupakan yang lebih berpengaruh untuk menjadikan siswa disiplin pada waktu. Karena kurang diawasi dalam pengunaan adroid sehingga siswa tersebut merasa bebas dan bermain sesuka hati sehingga melupakan kewajibannya sebagai siswa.

\section{Faktor Eksternal}

Faktor-faktor penyebab kepatuhan siswa kelas XI dalam mematuhi peraturan karena ada beberapa cara kontrol sosial guru pada siswa yang khususnya mengenai kerlambat yaitu: 


\section{Kontrol Sosial dengan Cara Lisan}

Cara ini menekankan pada usaha guru untuk mengajak, membimbing, dan memberikan nasehat kepada siswa agar dapat bertindak sesuai dengan aturan-aturan yang berlaku. Kontrol sosial secara lisan ini dilakukan dengan mengajak siswa menaati aturan yang berlaku dengan berbicara langsung. Kontrol sosial guru pada siswa yang terlambat yaitu dengan adanya kerja sama antara guru bimbingan konseling (BK), guru piket dan wali kelas dengan memberikan nasehat tentang gambaran bahwa perilaku keterlambatan siswa(i) itu agar tidak mengulangi lagi.

Kontrol sosial guru pada siswa(i) yang melakukan suatu pelanggaran tata tertib di sekolah dalam cara lisan yaitu dengan memberikan nasehat dan memberikan teguran lisan. Seperti halnya siswa yang datang terlambat datang ke sekolah dipanggil oleh gurunya dinasehati jangan terlambat lagi. Jika siswa/i melakukan suatu pelanggaran tertib di sekolah yaitu dengan memberikan teguran secara lisan, memberikan pengarahan agar tidak mengulangi lagi. Kontrol sosial guru dapat dilakukan antara lain melalui lisan serta tulisan seperti siswa menulis surat pernyataan dan guru mengirim surat panggilan orang tua. Kontrol sosial sekolah pada pelanggaran tata tertib siswa di sekolah yaitu lisan ketika sudah diperingati, tetapi masih mengulangi maka guru menyuruh siswa membuat surat pernyataan, dan surat panggilan orang tua.

Kontrol sosial guru secara lisan serta tulisan yaitu menyuruh siswa membuat surat pernyataan untuk tidak melakukan pelanggaran, jika melakukan maka siswa tersebut bersedia dipanggil orang tuanya ke sekolah ketemu pihak sekolah. Dampak Negatif dari sanksi yang diberikan adalah sebagian siswa itu ada yang susah menghafal dan al-qur'an jadi membutuhkan waktu yang lama untuk menghafal sehingga waktu belajar di kelas terpakai, karena lama masuk ketika guru menjelaskan siswa yang terlambat susah untuk mengikuti karena kurang paham ada rasa malas sehingga tidak mengikuti pembelajaran dengan serius. Siswa yang terlambat bertanya kepada siswa yang tepat waktu sehingga kelas ribut hal itu akan mengganggu konsentrasi guru yang mengajar dan juga para siswa/i yang sedang serius belajar.

\section{Hukuman (Menghafal Al-Qur'an dan GBLS)}

Cara ini bertujuan untuk mengembalikan siswa seperti sebelum melakukan pelanggaran itu terjadi, terlambat datang ke sekolah diberikan sanksi hukum berupa menghafal al-qur'an yang telah ditentukan oleh sekolah dan Gerakan Bersih Lingkungan Sekolah (GBLS) seperti, memungut sampah dan menyiram bunga (membersihkan lingkungan sekolah).

Hukuman yang diberikan guru kepada siswa yang terlambat adalah menyuruh siswa untuk menghafal al-qur'an sampai benar-benar hafal kalau belum hafal siswa yang terlambat tersebut tidak bisa masuk kelas. kemudian siswa juga melakukan kegiatan Gerakan Bersih Lingkungan Sekolah (GBLS) seperti memungut sampah di lingkungan sekolah, menyiram bunga baik yang di taman dan menyiram bunga yang ada di gedung lantai sampai lantai tiga bahkan juga membersihkan WC yang ada di lingkungan sekolah dalam setor hafalan siswa menyotor ke guru piket dan ketika GBLS disini wakil juga ikut mengawasi siswa dalam menjalankan sanksi hukuman yang di berikan. Jadi, siswa tidak ada yang main-main menjalankan sanksi hukuman tersebut, siswa serius mengerjakan sanksi tersebut karena siswa yang terlambat diawasi oleh guru piket dan juga wakil kepala sekolah. Semua itu dilakukan oleh pihak sekolah untuk kebaikan siswa, untuk mendidik para siswa SMA Negeri 2 Bukittinggi menjadi orang yang disiplin sesuai dengan misi sekolah. 
Guru memberikan contoh yang baik kepada siswa dan guru mampu melakukan kontrol sosial dan mengembalikan siswa yang melakukan pelanggaran tata tertib, karena tugasnya guru bukan hanya senantiasa mengajarkan mata pelajaran kepada anak didik tetapi juga mampu bagaimana membimbing perilaku anak didiknya sesuai dengan aturan yang ada sehingga anak didik menjadi pribadi yang bukan hanya cerdas tetapi patuh dan displin.

Dengan adanya kontrol sosial guru, saat siswa melakukan pelanggaran tata tertib di sekolah guru dengan tegas akan memberikan suatu sanksi sebagai upaya pemberian efek jera kepada siswa agar tidak mengulangi kesalahan yang sama. Oleh karena itu, seorang guru harus mampu melakukan kontrol sosial dan mengembalikan siswa yang melakukan pelanggaran. Kontrol sosial guru memang penting bagi siswa karena kontrol sosial guru sebagai pendekatan kepada siswa yang sering melakukan pelanggaran tata tertib perlu adanya kedekatan sehingga guru mudah memahami siswa-siswanya.

\section{Input Siswa Kelas XI SMA Negeri 2 Bukittinggi}

Berdasarkan hasil penelitian dengan beberapa informan mengatakan bahwa Penginputan kelas XI benar-benar diseleksi berdasarkan nilai tertinggi. Kelas XI yang sekarang merupakan siswa/i pilihan. Kalau yang sebelumnya itu semua siswa yang mendaftar itu diterima sehingga ada kelas itu sampai tidak muat. Namun, kalau kelas XI lebih patuh karena mereka merasakan betapa sulitnya masuk SMAN 2 Bukittinggi sehingga mereka berusaha untuk menaati peraturan yang ada, seperti dalam keterlambatan. Pada penerimaan kelas XI SMAN 2 Bukittinggi mereka benar-benar diseleksi baik itu nilai raport, nilai UN mengikuti test berupa test tertulis, psikotest, test IQ, test minat bakat dan mengisi angket dari BK.

\section{Ceramah dari Guru Mata Pelajaran yang Sedang Mengajar}

Ceramah dari guru mata pelajaran yang sedang mengajar dapat membuat siswa kelas XI mematuhi peraturan di SMA Negeri 2 Bukittinggi. Ketika guru mata pelajaran selalu menceramahi siswa/i yang terlamat mereka merasa dongkol dan siswa/i juga tidak suka kalau selalu mendengarkan ceramah setiap terlambat karena bosan dengan ceramah sehingga siswa/i yang terlambat menjadi tidak terlambat lagi.

\section{Faktor Internal}

Adapun faktor internal yang melatarbelakangi kepatuhan siswa kelas XI dalam mematuhi peraturan di SMA Negeri 2 Bukittinggi adalah:

\section{Takut Kepada Orangtua (Dimarahi Orang Tua)}

Siswa mematuhi peraturan di SMA Negeri 2 Bukittinggi karena takut kepada orangtua. Hal ini disebabkan karena ketika mereka terlambat dua kali orangtua langsung ditelfon dan terlambat tiga kali orangtua langsung dipanggil ke sekolah. Setelah orangtua mendengarkan penjelasan dari guru BK dan wali kelas informan siswa yang terlambat mengatakan orangtua siswa tersebut marah.

\section{Kesadaran Diri Sendiri}

Siswa kelas XI patuh terhadap aturan karena kesadaran diri sendiri. Hal ini disebabkan karena mereka sadar orangtua mereka yang memperjuangkan mereka untuk bisa sekolah, selain itu menurut siswa terlambat datang ke sekolah tu merupakan perbuatan yang tidak baik dan itu masalah buat diri kita sendiri dan juga orang tua. Siswa yang terlambat harus selesai setoran hafalan ayat al-qur'an baru bisa masuk kelas. Jadi masuk siswa itu pada jam kedua pelajaran. Dengan arti siswa rugi tidak bisa mengikuti jam pertama pelajaran pada hari itu dan ketika masuk siswa akan bingung untuk mengikuti materi selanjutnya, yang terjadi siswa 
yang terlambat juga mengganggu konsentrasi belajar. Guru yang masuk sudah mengajar dengan menjelaskan materi dan ada siswa yang masuk guru tersebut ceramah di dalam kelas menghabiskan waktu beberapa menit untuk ceramah dan siswa yang terlambat karena jam pertama tidak masuk dia akan menanya temannya tentang pelajaran yang telah dipelajari dan suasana kelas akan ribut. Ada juga siswa yang tepat waktu duduk di kursi siswa yang terlambat, ketika siswa yang terlambat masuk kelas kelas ada duduk di kursinya biasa sehingga siswa yang tepat waktu dan siswa yang tidak tepat waktu ribut ketika hendak bertukar posisi. Siswa yang terlambat sadar terhadap apa yang dilakukan bahwa mereka siswa yang terlambat merugikan dirinya sendiri dan juga orang lain akibat dari keterlambatan itu.

\section{Ejekan Teman-teman/Malu dengan Teman Sebaya}

Ejekan teman-teman bisa membuat siswa/i yang terlambat menjadi patuh pada aturan karena siswa/i yang terlambat merasa malu pada teman-teman sebayanya. Siswa/i yang hadir tepat waktu hadir di sekolah mengejek teman-temannya yang terlambat. Misalnya ketika siswa/i yang terlambat hendak masuk kelas ketika sudah sampai dipintu siswa yang berada didalam kelas mengejek dengan mengatakan "marilah kita sambut hafidz dan hafidzah qur'an kita!" sambil tertawa "hahaha", ada juga siswa/i yang di dalam kelas mengatakan "inilah dia hafidz dan hafidzah qur'an kita!" lalu tertawa "Hahaha" siswa yang didalam kelas (yang hadir tepat waktu) juga mengejek teman-temannya dengan mengatakan "kawan-kawan ala tibo hafidz dan hafidzoh qur'an kito agiahlah tepuk tangan kawan-kawan" artinya "kawankawan udah datang hafidz dan hafidzah qur'an kita berilah tangan kawan-kawan“" lalu mereka tertawa "hahaha".

\section{Merasa Tanggung Jawab Sebagai Siswa}

Mematuhi peraturan yang ada di sekolah seperti hadir tepat waktu datang ke sekolah merupakan tanggung jawab setiap siswa/i. Tidak terlambat datang ke sekolah termasuk tanggu jawab siswa. Merasa tanggung jawab sebagai siswa dapat menyebabkan kepatuhan pada aturan sekolah.

\section{Kontrol Sosial Guru di Kelas (Guru Mengajar Menghukum Siswa Yang Melangar Aturan Yang Telah Disepakati/ Kontrak di Awal Sekolah)}

Selain aturan yang dibuat sekolah. Guru mata pelajaran dan siswa juga ada membuat peraturan ketika diawal ajaran baru bahwa ada guru mata pelajaran terlambat 30 menit diberdirikan di depan kelas dengan arti siswa yang terlambat tetap bisa masuk kelas dan mengikuti pelajarn pada hari itu. Namun, sanksiny a siswa yang terlambat tersebut tidak bisa duduk di kursi. Ada juga guru mata pelajaran menghukum siswa yang terlambat 30 menit tidak bisa bisa ikut belajar didalam kelas dengan arti siswa yang terlambat diperpustakaan setelah. Namun, setelah jam prlajaran itu selesai pada har itu siswa menjumpai guru tersebutdan membuat surat perjanjian untuk tidak mengulangi katerlambatannya itu lagi. Kontrol Sosial Guru di kelas (Guru mengajar menghukum siswa yang melangar aturan yang telah disepakati) ini dapat membuat siswa menjadi patuh.

\section{Takut Nilai Kedisipinan Cukup (C)}

salah satu yang membuat siswa kelas XI SMA Negeri 2 Bukittinggi patuh dalam mematuhi peraturan di sekolah yaitu tentang keterlambatan adalah siswa/i takut apabila nilai sikap sosial mengenai kedisiplinan " $\mathrm{C}$ ". Menurut wali kelas dan siswa apabila nilai kedisiplinan " $\mathrm{C}$ " kemungkinan besar siswa/i akan tinggal kelas sehingga siswa kelas XI takut untuk terlambat. faktor pendorong yang membuat siswa kelas XI mematuhi peraturan di 
SMA Negeri 2 Bukittinggi patuh adalah karena takut nilai sikap yaitu kedisiplinan "C" apabila siswa dapat nilai "C" maka kemungkinan besar akan tinggal kelas.

\section{Motivasi Diri Sendiri (Ingin Menjadi Lebih Supaya Bisa Contoh Bagi Siswa Yang Lain)}

Siswa kelas XI patuh pada peraturan sekolah karena ada motivasi dalam diri siswa tersebut. Siswa yang terlambat menanamkan dalam diri bahwa akan berusaha untuk tidak terlambat, mengusahakan lebih awal datang ke sekolah karena berkeinginan dan membuktikan kepada diri sendiri, kepada teman-teman dan kepada guru-guru bahwa mereka bisa berubah dan bisa menjadi contoh bagi siswa yang lainnya.

Berdasarkan hasil penelitian yang telah peneliti uraikan diatas peneliti menganalisis dengan menggunakan teori kontrol sosial berdasarkan proposisi oleh Hirschi yang merupakan social bonds berfungsi untuk mengendalikan perilaku siswa. Pertama, attachemen atau kasih sayang sebagi sumber kekuatan yang muncul dari kelompok primernya yaitu keluarga. Disini kasih sayang orang tua dapat membuatsiswa patuh pada peraturan sekolah. Dengan adanya kontrol sosial yang dilakukan orang tua membuat siswa yang tadinya terlambat menjadi disiplin. Sesuai dengan yang telah diuraikan di atas bahwa untuk siswa yang terlambat karena disengaja dan orangtua sudah dipanggil ke sekolah dan disini orang tua siswa tersebut marah karena perbuatan anaknya tersebut, marah orang tua disini merupakan karena kasih sayangnya kepada anaknya, maksud dari kemarahnnnya adalah supaya anaknya patuh patuh pada peraturan yang telah ditetapkan oleh sekolah seperti tidak terlambat lagi. Sebagaimana yang telah peneliti urain di atas ternyata kemarah orang tua tersebut dapat membuat siswa yang terlambat menjadi patuh yang tadinya sering terlambat sudah belajar untuk tepat waktu.

Untuk siswa yang terlambatnya tidak disengaja tapi karena keadaan yang membuat yaitu angkutan umum yang membuat terlambat oarngtua berusaha membeli motor supaya siswa tersebut tidak terlambat lagi itu merupakan kasih sayang yang diberikan orangtua sehingga para siswa yang terlambat bisa mematuhi peraturan sekolah, berusaha untuk merubah untuk tidak terlambat.

Kedua, Commitment merupakan tanggung jawab yang kuat pada aturan dan hal ini memberikann kesadaran tentang masa depan. Pada penjelasan hasil wawancara telah peneliti jelaskan ada kontrol sosial dan sanksi yang tegas dari sekolah atas keterlambatan yang dilakukan membuat siswa menjadi patuh pada aturan yang berlaku. Mereka menyadari bahwa mematuhi perturan sekolah merupakan tanggung jawab dari setiap siswa, dan para siswa yang datang kesekolah bukanlah perilaku yang baik namun itu merupakan penyimpangan sosial. Tutur siswa yang terlambat mereka ke sekolah adalah untuk melatih diri membiasakan diri untuk tidak terlambat. Mereka tidak mau kalau waktu yang seharusnya digunakan untuk belajar malah terbuang karena menjalankan sanksi yang diberikan guru piket. Para siswa yang terlambat juga sadar bahwa adanya aturan yang telah ditetapkan sekolah itu merupakan untuk kebaikan siswa itu sendiri agar membiasakan disiplin waktu dan untuk membahagiakan orangtua. Siswa kelas XI sadar bahwa masuk SMA Negeri 2 Bukittinggi itu susah jadi tidak ingin menyia-nyiakan kesempatan itu. Disini teman sebaya atau teman-teman sebaya juga membantu untuk menyadarkan siswa siswa yang terlambat bahwa perilaku terlamat itu bukanlah suatu perbuatan yang baik, walaupun penyampaiannya melalui ejekan.

Ketiga, Involvement karena kesadaran membuat individu terdorong berperilaku partisipatif dan terlibat dalam ketentuan-ketentuan yang telah ditetapkan oleh sekolah. Di sekolah setiap hari senin upacara bendera dan setiap hari jum'at ada kultum setiap pagi ada mengatur lalu lintas khususnya di depan sekolah untuk membantu para siswa menyebrang jalan. Keterlibatan siswa dalam aktivitas-aktivitas seperti ini akan dapat membantu mengurangi peluang untuk terlambat. 
Keempat, Believe atau kepercayaan, kesetiaan dan kepatuhan pada norma-norma sosial atau aturan sekolah pada akhirnya akan tertanam kuat pada siswa. Kontrol dan sanksi tegas yang diberikan sekolah memberikan dampak positif bagi siswa yang terlambat menjadikan siswa patuh pada aturan dan percaya bahwa apabila mereka melanggar peraturan seperti akan dapat nilai kedisiplinan Cukup dan apabila nilai itu " $C$ " kemungkinan besar akan tinggal kelas karena sudah terbukti teman mereka ada yang tinggal kelas sehingga para siswa takut akan hal itu. Para siswa juga mempercayai bahwa dengan mematuhi peraturan bisa menjadi teladan bagi yang lain hal itu menjadi salah satu motivasi siswa yang terlambat untuk mematuhi peraturan yang ada. Mereka berusah untuk tidak terlambat dan lebih awal ke sekolah untuk membuktikan kepada diri sendiri, orang tua, guru-guru dan teman-teman bahwa mereka pasti akan bisa menjadi lebih baik.

\section{Kesimpulan}

Penyebab keterlambatan siswa ada yang disengaja karena kelalaian siswa seperti seperti main game online sampai larut malam, menonton drama korea sampai larut malam, tidak mempersiapkan perlengkapan sekolah pada malam harinya seperti buku seragam sekolah dan perlengkapan sekolah lainnya, mengerjakan PR pagi hari, siswa yang dekat rumahnya dengan sekolah menunggu bel berbunyi terlebih dahulu. Keterlambatan tidak di sengaja karena menunggu angkot penuh terlebih dahulu.

Kepatuhan siswa kelas XI dalam mematuhi peraturan di SMA Negeri 2 Bukittinggi terdiri dari dua faktor yaitu faktor eksternal dan internal. Faktor Eksternal yaitu, kontrol sosial dengan cara lisan, Hukuman yang telah ditetapkan sekolah, input siswa kelas XI SMA Negeri 2 Bukittinggi dan Ceramah dari guru mata pelajaran yang sedang mengajar. Faktor internal yaitu, takut kepada orang tua (dimarahi orang tua), kesadaran diri sendiri, ejekan teman-teman/ malu dengan teman sebaya, merasa tanggung jawab sebagai siswa, kontrol sosial guru di kelas (guru menghukum siswa yang melanggar aturan telah disepakati/ Kontrak awal sekolah), takut nilai kedisiplinan cukup (C), motivasi diri sendiri (ingin menjadi lebih baik supaya bisa contoh bagi siswa yang lain. Penemuan penelitian menggambarkan secara umum kedisiplinan siswa kelas XI untuk tidak terlambat ke sekolah semakin meningkat. Walaupun keterlambatan siswa ini sebenarnya belum semuanya bisa disiplin secara total. Namun, sebagian besar siswa yang terlambat sudah bisa hadir tepat waktu datang ke sekolah.

\section{Daftar Pustaka}

Apriliani Fitri. (2015). Upaya Guru dalam Meningkatkan Kedisiplinan Siswa di SMA PP DR M.Natsir Batu Bagiriak Kecamatan Lemah Gumanti Kabupaten Solok. Jurnal. jim.stkip-pgri-sumbar-ac.id

Asrori. (2004). Psikilogi Remaja Perkembangan Peserta Didik. Jakarta: PT Bumi Aksara

Blass, T. (1999). The Milgram Paradigm After 35 Years: some Things we now know about abdience to Authirity. Journal of Applied Social Psychologi. 29, 5 hal 957

Julia, E. (2013). Analisis Faktor Penyebab dan Upaya Mengatasi Pelanggaran Tata Tertib Sekolah pada SMA Wisuda Pontianak. Artikel. Jurnal.untan.ac.id

Kholid, U. dan E. M. S. (2011). Pengantar Sosiologi Pemahaman Fakta dan Gejala Permasalahan Sosial: Teori, Aplikasi dan Pemecahannya. Jakarta: Kencana Prenada Media Group

Meleong J. Lexy. (2009). Metode Penelitian Kualitatif. Jakarta: Kencana Prenada Media Group

Jurnal Perspektif: Jurnal Kajian Sosiologi dan Pendidikan Vol. 2, No. 3, Th. 2019 
Rahmawati, A. D. (2015). Kepatuhan Santri Terhadap Peraturan di Pondok Pesantren. Skripsi. eprints.ums.ac.id

Siswanto, H. (2001). Pengantar Manajemen. Jakarta: Bumi Aksara

Suyanto Bagong dan J. Dwi Narwoko. (2011). Sosiologi: Teks Pengantar dan Terapan. Jakarta: Kencana

Tsania Rizqi Laila. (2018). Hubungan Kekuatan Karakter dan Kepatuhan Santri pada Peraturan Pondok Pesantren. Skripsi. digilib.uin-suka.ac.id

Yahya. (2018). Administrasi dan Supervisi Pendidikan. Padang: UNP PERS 